\title{
Peter Dykes
}

\section{The Quasi-Market Approach: the answer for social housing in New

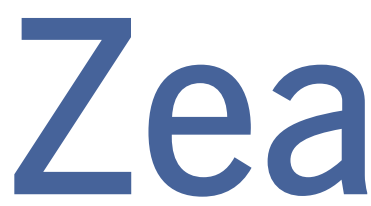 land?}

One of the major current policy initiatives of the New Zealand government is the introduction of the quasi-market approach for the delivery of social housing under the Social Housing Reform Programme. The Social Housing Reform Programme seeks to increase the participation of third-party not-for-profit community housing providers in delivering social housing in competition with Housing New Zealand Corporation (Minister of Housing, 2012). What has become known as the 'quasi-market' approach in social policy is based on the idea of creating competition and using market-based incentives. The rationale of this approach is that if prices are based more on supply and demand, then resource allocation will be more efficient. Applied to housing, the argument is

This article is based on a research paper by Peter Dykes, submitted as part of the requirements for a Master of Public Policy degree through the School of Government at Victoria University of Wellington. that providers will respond to increased market demand for rental accommodation by increasing supply, and competition between providers will induce more responsiveness to the needs of tenants, which will lead to higher quality and more choice and better constrain rental costs (Le Grand and Bartlett, 1993).

\section{Background}

Social housing can mean different things in different contexts and countries (Kemeny, 2007). In New Zealand, Housing New Zealand Corporation, a stateowned enterprise, with approximately 68,000 social housing units, provides the overwhelming majority (94\%) of social housing. Housing New Zealand tenants pay an income-related rent limited to $25 \%$ of household income, up to an income threshold. The government pays Housing New Zealand an incomerelated rent subsidy (IRRS), being the difference between the income-related 
rent paid by the tenant and the assessed market rental value of the property. Social housing in New Zealand is 'residualised' (Kemeny, Kersloot and Thalmann, 2005), characterised by strict means-tested access with prioritisation based on severity of need, and is therefore the preserve of the poor. In addition to Housing New Zealand, local authorities provide approximately 9,000 social housing units (mostly in Christchurch and Wellington), while a small number of regionallybased community housing providers, with around 5,000 units in total, provide supported accommodation, typically focused on a specific sector such as people with physical or mental disability (Housing Shareholders' Advisory Group, 2010; Treasury, 2014).

Under the Social Housing Reform Programme the government:

- has extended access to the incomerelated rent subsidy to community housing providers on the same basis as Housing New Zealand to establish funding neutrality. The aim is develop a plurality of providers, increasing competition and the supply of social housing accommodation. The income-related rent subsidy provides the income stream for community housing providers to cover operating, funding and maintenance costs;

- has initiated large-scale stock transfers from the Housing New Zealand portfolio to community housing providers, initially planning to sell 2,000 state houses with existing tenants in place, in order to create competitors of 'scale' with Housing New Zealand; and

- will 'purchase' a specific number of income-related rent subsidies from the 'market' (i.e. some aggregate of Housing New Zealand and community housing providers), thereby controlling its expenditure on social housing and enabling the government to compare providers to 'ensure that they get the most efficient supply options'. (Minister of Housing, 2012, p.9)

The new policy, the government believes, will increase tenant choice, enhance the quality of housing, and address equity issues through better incentive structures and regulation.

Le Grand and Bartlett (1993) propose a number of criteria for assessing whether the conditions for the successful establishment of a quasi-market have been met. The criteria include: the degree to which a competitive market structure is established; the impact on 'transaction costs' associated with risk and uncertainty, requiring complex contractual negotiations and regulatory costs; the impact of market disciplines on the motivation and entry of new providers; and the potential for 'cream skimming' (i.e. the extent to which discriminatory or opportunistic behaviour arises under
Treasury acknowledges that the evidence to support such assumptions is limited and difficult to quantify (Treasury, 2012, 2015). Overseas experience highlights that even in situations such as in England in the 1990s, where conditions and policies were much more conducive than in the current New Zealand context, effective competition did not emerge. Geographic market power was retained, mergers and acquisitions were common to gain scale, and agreements not to compete were reached, especially around development land (Bramley, 1993; Gibb, 2005). In New Zealand the outlook for the establishment of a competitive social housing market is not promising.

\section{One of the requirements of a successful quasi-market approach is to create a competitive market and allow prices to respond to supply and demand, and therefore drive productive and allocative efficiency ...}

a quasi-market model). This article draws on these criteria and overseas evidence to assess whether the government's reforms to social housing are likely to achieve their stated objectives. It also looks briefly at alternative policy directions.

\section{Establishing a competitive market structure} Creating effective competition

One of the requirements of a successful quasi-market approach is to create a competitive market and allow prices to respond to supply and demand, and therefore drive productive and allocative efficiency (Le Grand and Bartlett, 1993). To achieve this the government has extended the market-linked income-related rent subsidy to community housing providers. It is assumed that, with access to this subsidy, capital (i.e. philanthropic equity and private loan capital) will be attracted to the social housing sector, thereby increasing the number of providers. This will enhance competition and increase the supply of social housing. However, the
The government initially provided capital subsidies to community housing providers of up to $50 \%$ of the cost of social housing units. However, the Treasury advised the government that, at the forecast level of capital expenditure on social housing units, it would be 'hard to say that a functioning, competitive market was in place or on the way to being created' (Treasury, 2012, p.5). Despite some initial transactions, capital subsidies were deemed ineffective and expensive and are not being pursued. The policy focus therefore shifted to large-scale stock transfers, similar to the approach in England in the 1990s, in order to provide competitors with scale to compete with Housing New Zealand. According to Treasury, the Housing New Zealand portfolio would need to be less than $70 \%$ (compared to the current 94\%) of the social housing market to generate sufficient competition. This implies that more than 20,000 houses will need to be transferred to community housing providers before 
competition can effectively emerge. Furthermore, the Treasury advises that between 500 and 1,500 units would be the 'minimum' required to achieve providers of 'scale' (Treasury, 2012). However, the New Zealand community housing sector has been described as 'boutique' (Capital Strategy/SGS Economics and Planning, 2007), with the Housing Stakeholders' Advisory Group (2010) estimating that existing providers typically have only 20 units (Housing Stakeholders' Advisory Group, 2010). This implies the need for a substantial increase in the size of community housing providers' social housing portfolios and raises questions 'capital investment or subsidies are often needed for a significant period of time before providers become self-sustaining' (Treasury, 2010b, p.6). The social housing minister cites community housing provider uptake of social housing in Australia as an example of the success of increasing the sector's involvement in social housing (Bennett, 2015a). However, Yates (2013) highlights that Australian community housing providers' involvement in social housing was stimulated by the Australian Federal Labour government's A $\$ 5.6$ billion investment in supply- and demand-side subsidies in 2009 as part of a response to the global financial crisis. The minister

\section{... under the current IRRS model ... there is a substantial 'gap' between what Housing New Zealand earns and what a 'reasonable commercial provider would need to earn in order to cover the cost of capital' ...}

about how such an expansion is to be funded and managed.

\section{Lack of capital a 'fundamental barrier'}

The government recognises that a 'fundamental barrier' to such an expansion is the 'shallowness' of the community housing sector's capital base. This is most acutely felt in high-value areas, which also have the highest level of unmet demand, thereby exacerbating the problem (Minister of Finance and Minister of Housing, 2014). This represents an inherent contradiction in the policy logic, given that one of the original primary drivers of the policy was the purported ability of community housing providers to access capital from 'multiple public and private philanthropic sources' (Minister of Housing, 2012, p.9).

\section{Capital subsidies will be required}

The community housing sector has called for upfront capital grants to assist it in purchasing or developing social housing (Davidson, 2015). The Treasury notes that overseas evidence indicates that cites Trust House in Masterton as an example of community housing providers delivering social housing in New Zealand. However, the unit growth for Trust House has been 'less than one unit per year over its history and [it] still depends on a government loan at zero interest in order to be financially sustainable' (Bennett, 2015b; Norman and Teahan, 2015, p.55).

Overall, the emergence of competition or an increase in social housing supply via community housing providers are unlikely given the current boutique scale, sector capital constraints and absence of capital subsidies. The need for capital subsidies will likely remain a key policy requirement for community housing provider participation.

\section{Efficiency and effectiveness under the IRRS approach}

Despite the evidence of the need for capital subsidies, the government has instead chosen to rely almost entirely on the demand-side, market-linked incomerelated rent subsidy to encourage private providers to enter the social housing market. Accordingly, little progress is likely. Indeed, Treasury has argued that establishing a contestable IRRS pool will not be a 'particularly efficient or effective way to grow future supply' (Treasury, 2013, p.6).

Financial viability of social housing under the IRRS model

The Treasury identifies that, in addition to the lack of capital noted above, low investment returns are a significant barrier to community housing providers investing in social housing (Treasury, 2012). KPMG modelling of social housing costs for Australian community housing providers highlights low returns as a key factor inhibiting supply growth (cited in Yates, 2013). The KPMG study indicates that return on assets ranges between $0.3 \%$ and $1.4 \%$, which is not adequate to accumulate cash for future growth. This range of returns, however, is similar to that calculated for Housing New Zealand and deemed unacceptable for the New Zealand government (Minister of Housing, 2012). The financial viability of the New Zealand approach may be even more problematic given that the government is seeking to achieve 'market' value for the houses (Key, 2015), while under the Australian model the houses are transferred to community housing providers 'at no cost and no debt obligation' (Yates, 2013, p.22).

According to the Treasury, under the current IRRS model, as applied to Housing New Zealand, there is a substantial 'gap' between what Housing New Zealand earns and what a 'reasonable commercial provider would need to earn in order to cover the cost of capital' (Treasury, 2012, p.6). In a residualised social housing model the gap is maximised, given that most tenants' incomes are based on a welfare benefit. The implication is that the gap may well be the same for community housing providers, and they may have even higher per-unit costs and therefore a higher subsidy requirement (Treasury, 2013).

\section{IRRS as a driver of efficiency benefits}

In traditional markets, allocative efficiency is achieved through prices reflecting supply and demand. However, as the Treasury (2012) acknowledges, with social 
housing based on need rather than price, a true market is unlikely to emerge. In New Zealand, as overseas (Gibb, 2005), the market rental prices which determine the value of the IRRS for social housing providers are set by the government and providers, largely without tenant input. The government intends to use its position as a monopoly funder and purchaser through the Ministry of Social Development to override the 'market' by specifying units of modest quality and amenity value, and apply a maximum rate that it is prepared to pay, based on the lower two market quartiles (Kirk, 2015). This will suppress price signals and undermine allocative efficiency (Bramley, 1993). In addition, Treasury notes that, as a means of generating productive efficiency, the IRRS approach is likely to be 'ineffective' as it 'removes any tension over prices between the provider and the tenants' (Treasury, 2010a, p.8). The centralised allocation process for social housing is unlikely to lead to improved services or lower rents until there is a surplus in capacity, especially in high-demand areas (MacLennan and More, 1997). Longerterm contracts guaranteeing access to the IRRS (Bennett, 2015a) will likely further undermine efficiency benefits, as, once the initial contract has been negotiated, the contract is 'transformed' into a long-term supply arrangement, reducing competing bidders (Tadelis and Williamson, 2012).

\section{Tenant choice}

It is suggested that competition will improve tenant choice. For effective tenant choice there must be spare capacity, or 'slackness', of appropriately configured accommodation within the same geographic area in order to engender competition between Housing New Zealand and community housing providers (MacLennan and More, 1997). Given the conclusion that there is unlikely to be a significant increase in competition, waiting lists will remain, undermining effective tenant choice. In a residualist model like New Zealand's, with social housing centrally allocated and provided only to those in serious need (often after long waiting times), vulnerable families with high needs are likely to take the first rental offered (either by Housing
New Zealand or a community housing provider) rather than choosing between several options (Boyle, 2015). In addition, the policy maylead to an increase in waiting times, given that, to ensure fiscal control, the Ministry of Social Development will be provided with a capped budget for subsidies. The Treasury advises, therefore, that the ministry will now not only need an appropriate property to be available, but will also need the capacity to fund an additional subsidy (New Zealand Treasury, 2013).

\section{For the quasi-market approach to be cost-effective, the purported benefits from increased competition must be greater than the transaction costs.}

increase in supply. This is similar to the current situation in New Zealand (Treasury, 2015a). Alternative funding models, where capital subsidies are contributed upfront and rents are set based on costs, avoid the rental subsidy rising in tandem with rising property values (PricewaterhouseCoopers and L\&Q, 2014). This raises serious questions about the structural ability to reduce social housing expenditure over the longer term under the Social Housing Reform Programme.
Effective choice is further undermined by the new social housing allocation rule. This reduces the number of social housing choices a family can decline to one before being subject to a 13-week stand-down period (Bennett, 2015c).

\section{Cost-effectiveness of the IRRS model}

The IRRS funding model may also be the most expensive option for the government over the medium to long term. The prime minister, John Key, argues that it is more cost-effective paying $\$ 12$ million per annum in income-related rent subsidies to community housing providers than the government investing $\$ 500$ million in building 1,000 houses (Hickey, 2015). However, analysis of funding options for social housing in England indicates that the option similar in principle to the IRRS (i.e. zero capital subsidies, full market rent but subsidised rents for tenants) will be the most expensive option over the medium to long term (ten years or more) (PricewaterhouseCoopers and L\&Q, 2014). This is because the cost of the subsidy is linked to property prices and rental inflation, which normally rise faster (especially in high value, high demand areas) than social housing tenants' incomes. This increases the level of the required subsidy but does not lead to a commensurate

\section{Transaction costs}

For the quasi-market approach to be costeffective, the purported benefits from increased competition must be greater than the transaction costs. Transaction costs take the form of detailed contractual negotiations, and compliance, inspection and enforcement costs, to protect each party's property rights. With high levels of complexity and uncertainty, it may be more cost-effective to internalise production within an organisation, avoiding the need, ex ante, to codify all future circumstances and contingencies into a contract (Tadelis and Williamson, 2012). Under the Social Housing Reform Programme, 'right size, right place' risks currently born by the government are effectively being transferred to community housing providers. The risk for community housing providers is that, because of changing client needs, market conditions or new providers, the government does not renew or seeks to renegotiate terms and conditions. Realisation of such risks would significantly undermine the value of the community housing provider's social housing portfolio, raising asset specificity risks. Mitigation of such risks requires contractual protection, raising complexity and costs, especially where a consortia approach is adopted (Chapman 
Tripp, 2015). In addition, the cost of the regulatory framework should not be underestimated. British evidence shows an increasing regulatory burden, as well as difficulties of enforcement if tenants are not to be adversely affected (Chisholm, 2015; Gibb, 2005; Adams, Tiesdell and Weeks, 2010).

\section{Motivation of providers}

Much of the success in using a quasimarket approach relies on the aspiration of individual community housing providers to grow. But such organisations have diverse motivations and may not have the objective to grow, or be willing to take on the associated risks (Bramley, often have complex needs and these can be costly to service. If community housing providers have the ability to decline tenants or focus on particular segments of the market they may 'cherry pick' the lowestcost clients or discriminate on gender, ethnicity, religious or other grounds. British evidence indicates that some housing associations did discriminate against highcost tenants (Bramley, 1993). In respect of social housing in New Zealand, this may increase the concentration of high-need and costly tenants within the Housing New Zealand portfolio, undermining Housing New Zealand's ability to provide adequate service levels and leading to further marginalisation of those in its portfolio.

\section{Overall, the new Social Housing Reform Programme lacks internal consistency and is unlikely to achieve the purported benefits.}

1993). For example, in Australia not all community housing providers utilise the ability to leverage acquired assets (Yates, 2013). In addition, the quasi-market approach has, for profitability reasons, seen a shift in focus to affordable housing based on 'mixed' tenure developments, with - in the UK - 'inclusionary zoning' requirements used to specify a minimum number of social housing units (Chevin, 2013). Such approaches severely limit the supply of new social housing stock, leading to an overall decline in the total supply of social housing (Thornhill, 2010). The same approach is being followed in New Zealand. For example, the Tāmaki regeneration project has the un-aspirational target that the number of social housing units will not diminish (Moir, Kirk and Carnegie, 2015).

\section{Cream skimming}

Currently, under Housing New Zealand the allocation of social housing is based on need. Housing New Zealand cannot exercise a choice not to provide a house if the tenant meets the relevant criteria and one is available. In a residualist model, tenants

\section{Summary}

The preceding analysis suggests that the government's Social Housing Reform Programme is most unlikely to achieve its goals of increasing third-party participation, improving the efficiency of the delivery of social housing and significantly increasing total supply. Indeed, the policy appears to be inherently flawed. It seeks to increase social housing by accessing the capital resources of the community housing sector, but it is acknowledged that one of the major constraints is the 'shallowness' of the capital pool within that sector. This inherent contradiction limits the degree to which competition can emerge and supply increase, which then undermines improvements in efficiency, responsiveness, or choice for tenants. However, rather than addressing this issue through capital subsidies, the policy offers only the demand-side IRRS. Yet there are real concerns as to the financial viability of social housing under the IRRS model. At the same time, the IRRS model will likely be the most expensive option for the funding of social housing over the medium to long term, given that the subsidy increases with market prices but does not lead to commensurate additional supply. The rent-setting process under the IRRS model will likely only allow for a weak relationship between prices and market conditions, undermining any improvement in allocative efficiency. The motivation for community housing providers to be involved in delivering social housing may be constrained by commercial imperatives. The centralised allocation process and ongoing lack of supply is unlikely to increase effective tenant choice. Finally, significant equity concerns may arise where community housing providers have the opportunity to decline tenants, leading to discrimination and cream skimming as high-cost tenants are excluded in favour of those with lower costs.

\section{Alternative policy options}

If a core goal of social housing reform is to satisfy unmet need in a cost-effective manner, then other policy options must be considered. Four possibilities are briefly outlined here.

\section{Increase funding for Housing New Zealand}

The first option is to abandon the proposed reforms and focus on expanding the stock of housing via an increased level of public investment through Housing New Zealand. Given Housing New Zealand's economies of scale and scope, and access to existing land and resources, it may well be able to deliver a significant increase in social housing more quickly and cost-effectively than community housing providers. Evidence suggests that, historically, substantial increases in supply have been associated with public investment (Brandsen and Helderman, 2006; MacLennan and More, 1997; Yates, 2013). If, for example, Housing New Zealand's Tāmaki development (Tāmaki Redevelopment Company, 2015) focused on maximising social housing rather than attempting to offset project costs by developing for-profit affordable housing, a meaningful increase in social housing could be achieved.

\section{Provide capital subsidies to community} housing providers

The second option is to re-establish capital subsidies for community housing 
providers. Lack of capital is identified as one of the main constraints on the community housing sector for increasing supply growth (Davidson, 2015; Minister of Finance and Minister of Housing, 2014). The main advantage of this approach is that capital grants or subsidies would reduce the risk for community housing providers, allow their limited capital to stretch further and enhance their ability to secure private funding. This option would need to include a reconsideration of the IRRS model and a shift to a cost-based rental system, which is likely to be a more cost-effective solution over the medium to long term (PricewaterhouseCoopers and L\&Q, 2014).

\section{Gifting of stock}

The third option is to adopt the Australian approach and transfer the assets free of charge to community housing providers. The advantage of this approach is that it minimises capital contributions from the government, but with a withdrawal of equity being reflected through the revaluation of the Housing New Zealand portfolio. The disadvantage is that there is less cash to recycle into social housing (Treasury, 2015), and it may still be insufficient to induce supply growth (Yates, 2013).

\section{Development of a cost-based rental sector through community housing providers}

The fourth option is to embark on a transformational programme, turning social housing away from a residualist, needs-based model of the kind currently evident in New Zealand to a model of costbased rental accommodation provided by community housing providers, closer to that witnessed in parts of Europe, such as the Netherlands. The Treasury advises that, rather than seeing home ownership as the path to independence (Minister of Housing, 2012), for those currently in the residualist form of social housing support should be provided, to develop a longterm, affordable rental accommodation market (Treasury, 2012b).

In the Netherlands and other parts of Europe, community housing providers have been used extensively to provide access to affordable housing on a cost rental basis, and with long-term security of tenure. Social housing in this context is open to a much broader segment of the population. Access is not means-tested, although it is prioritised on need (Kemeny, 2007; Scanlon and Whitehead, 2008). Rents are set based not on the market but on actual costs of management, maintenance and capital, allowing rents to be kept low when housing is provided by not-for-profit entities. One of the effects of the cost-based rental approach is that it provides more choice of tenure and higher levels of responsiveness through greater competition, and efficiency by, over time, driving down prices in the forprofit rental market (Davidson, 1999).

Developing this form of social housing has decided merit in the context of the housing affordability crisis in Auckland and the emergence of 'generation rent', who increasingly seek affordable and secure rental housing (Eaqub and Eaqub, 2015). This will be of increasing importance over time, with higher numbers of New Zealanders reaching retirement age without having achieved home ownership (Statistics New Zealand, 2013). While significant public resources would be required, it may be more politically acceptable given that the policy targets a growing segment of the mainstream population.

\section{Conclusion}

The justification for introducing the quasimarket approach in social housing in New Zealand is that it will increase allocative and productive efficiency, provide access to alternative sources of capital, increase supply, and enhance the choice of provider and quality of accommodation for tenants. The preceding analysis raises serious questions about the validity of each of these claims in relation to the recent social housing reforms. Overall, the new Social Housing Reform Programme lacks internal consistency and is unlikely to achieve the purported benefits. Indeed, there is a risk that some of those with the most serious housing needs will be worse off. Accordingly, other policy options require consideration. Arguably, the best long-term approach would be to adopt a policy framework closer to that of countries like the Netherlands and develop a cost-based rental housing sector, where good quality, secure and affordable rental accommodation is available to a much broader segment of the New Zealand population than has hitherto been the case. However, to make such a transition would require political leadership, multiparty commitment and sustained capital investment over several decades.

\section{References}

Adams, D., S. Tiesdell and G. Weeks (2010) Delivering Better Places in Scotland: a guide to learning from broader experience, Glasgow: Scottish Government, retrieved from http://www.gov.scot/Resource/ Doc/336587/0110158.pdf

Bennett, P. (2015a) 'Opening Community Housing Aotearoa's 2015 conference', https://www.beehive.govt.nz/speech/opening-communityhousing-aotearoa's-2015-conference

Bennett, P. (2015b) Social housing minister Paula Bennett interviewed by Corin Dann, $Q+A$, Television New Zealand

Bennett, P. (2015c) 'Social housing changes to house people sooner', media release, 5 November, retrieved from http://www.beehive.govt. $\mathrm{nz} /$ release/social-housing-changes-house-people-sooner
Bennett, P. (2015d) 'Social Housing Reform Programme: initial steps and future state for purchasing social housing places for clients (paper two)', Wellington: Office of the Minister of Social Housing, retrieved from http://www.msd.govt.nz/documents/about-msd-and-our-work/ work-programmes/social-housing/cabinet-papers/social-housing-reformprogramme-initial-steps-and-future-paper-2.pdf

Boyle, D. (2015) Equality, Equity and Choice, retrieved from https://www. britishcouncil.org/sites/default/files/dk_d160_book_2_equality_equity_ and_choice_david_boyle.pdf

Bramley, G. (1993) 'Quasi-markets and social housing', in J. Le Grand and W. Bartlett (eds), Quasi-Markets and Social Policy, London: Macmillan 
Brandsen, T. and J.-K. Helderman (2006) 'The rewards of policy legacy: why Dutch social housing did not follow the British path', in L. Heyse et al., Reform in Europe: breaking the barriers in government, Aldershot: Ashgate

Capital Strategy/SGS Economics and Planning (2007) Affordable Housing: the community housing sector in New Zealand, Wellington, retrieved from http://www.chranz.co.nz/pdfs/community-housing-report.pdf

Chapman Tripp (2015) 'More light shed on social housing transfers', Brief Counsel, 30 April, retrieved from http://www.chapmantripp. com/publications/Pages/More-light-shed-on-social-housing-transfers. aspx?utm_source $=$ Mondaqandutm_medium = syndicationandutm _ campaign $=$ View-Original

Chevin, D. (2013) Social Hearted, Commercially Minded: a report on tomorrow's housing associations, Smith Institute, retrieved from http:// www.d4multimedia.com/genesis/Social-hearted.pdf

Chisholm, E. (2015) 'England's new regulations to protect tenants from retaliatory evictions', blogpost at One Two Three Home, http:// onetwothreehome.org.nz/2015/08/21/englands-new-regulations-toprotect-tenants-from-retaliatory-evictions/

Davidson, A. (1999) 'Alternative models of social housing: tenure patterns and cost-renting in New Zealand and Sweden', Housing Studies, 14 (4), pp.453-72, doi:10.1080/02673039982722

Davidson, I. (2015) 'Community housing providers "need to be sustainable businesses"', New Zealand Herald, 22 October

Eaqub, S. and S. Eaqub (2015) Generation Rent: rethinking New Zealand's priorities, Wellington: Bridget Williams Books

Gibb, K. (2005) The Social Housing Quasi-Market, research paper 4, Glasgow: Centre for Policy Studies for Regions

Hickey, B. (2015) 'PM John Key to focus on social housing in State of the Nation address: scale of state house sales, size of rent subsidies and use of NGOs key issues', retrieved from http://www.interest. co.nz/property/73726/pm-john-key-focus-social-housing-state-nationaddress-scale-state-house-sales-size

Housing Shareholders' Advisory Group (2010) Home and Housed: a vision for social housing in New Zealand, Wellington

Kemeny, J. (2007) 'Corporatism and housing regimes', Housing, Theory and Society, 23 (1), pp.1-18

Kemeny, J., J. Kersloot and P. Thalmann (2005) 'Non-profit housing influencing, leading and dominating the unitary rental market: three case studies', Housing Studies, 20 (6), pp.855-72

Key, J. (2015) 'John Key speech: next steps in social housing', retrieved from http://www.stuff.co.nz/national/politics/65496919/John-KeySpeech-Next-steps-in-social-housing

Kirk, S. (2015) 'Government releases social housing details', www.stuff. co.nz, 15 April

Le Grand, J. and W. Bartlett (eds), Quasi-Markets and Social Policy, London: Macmillan

MacLennan, D. and A. More (1997) 'The future of social housing: key economic questions', Housing Studies, 12 (4), pp.531-47

Minister of Finance and Minister of Housing (2014) 'Next steps in building the social housing market', Wellington: Cabinet Social Policy Committee
Minister of Housing (2012) 'Delivering social housing reform', Wellington: New Zealand Government, retrieved from www.mbie.govt.nz

Moir, J., S. Kirk and T. Carnegie (2015) 'Government offloads 2800 state houses to Auckland development company', www.stuff.co.nz, 30 April

Norman, R. and B. Teahan (2015) 'Growing community housing: challenges for government policy makers', Policy Quarterly, 11 (2), pp.54-9

PricewaterhouseCoopers and L\&Q (2014) The Numbers Game: increasing housing supply and funding in hard times, retrieved from https://www. pwc.ie/media-centre/assets/publications/2014-pwc-ireland-increasinghousing-supply-and-funding-in-hard-times.pdf

Sachevda, S. (2015) 'Plans to bump people off state housing list "unwarranted attack" - Labour', www.stuff.co.nz, 24 November

Scanlon, K. and C. Whitehead (2008) Social Housing in Europe II: a review of policies and outcomes, London: London School of Economics

Statistics New Zealand (2013) Housing in Auckland: trends in housing from the census of population and dwellings 1991 to 2013, Wellington: Statistics New Zealand, retrieved from http://www.stats. govt.nz/browse_for_stats/people_and_communities/housing/aucklandhousing-1991-2013.aspx

Tadelis, S. and O.E. Williamson (2012) 'Transaction cost economics', in R. Gibbons and J. Roberts (eds), The Handbook of Organizational Economics, Princeton: Princeton University Press

Tãmaki Redevelopment Company (2015) 'First new houses at Fenchurch opened', retrieved from http://www.tamakiregeneration.co.nz/news/ tamaki-news/first-new-houses-fenchurch-opened/

Thornhill, J. (2010) Allocating Social Housing: opportunities and challenges, Coventry: Chartered Institute of Housing

Treasury (2010a) 'Cabinet Strategy Committee discussion on the direction for social and affordable housing', retrieved from http://www.treasury. govt.nz/statesector/socialhousing/pdfs/sh-1928979.pdf

Treasury (2010b) 'Housing Shareholders' Advisory Group report: initial comments', retrieved from http://www.treasury.govt.nz/statesector/ socialhousing/pdfs/sh-1830212.pdf

Treasury (2012) 'Social housing and the four year budget plan', retrieved from http://www.treasury.govt.nz/statesector/socialhousing/pdfs/sh2269557.pdf

Treasury (2013) 'Contestable financial assistance for social housing: where to for IRRS?', retrieved from http://www.treasury.govt.nz/ statesector/socialhousing/pdfs/sh-2568979.pdf

Treasury (2014) 'Joint housing ministers meeting, Wednesday 15th October: the current shape of the New Zealand housing market', retrieved from http://www.treasury.govt.nz/statesector/socialhousing/ pdfs/sh-3133088.pdf

Treasury (2015) 'Social housing: alternative uses for Crown assets', retrieved from http://www.treasury.govt.nz/statesector/socialhousing/ pdfs/sh-2586724.pdf

Yates, J. (2013) 'Evaluating social and affordable housing reform in Australia: lessons to be learned from history', International Journal of Housing Policy, 13 (2), pp.111-33 